\title{
Copper complex catalyzed asymmetric monosulfonylation of meso-vic-diols
}

\author{
Yosuke Demizu, Kazuya Matsumoto, Osamu Onomura, ${ }^{*}$ and Yoshihiro Matsumura \\ Graduate School of Biomedical Sciences, Nagasaki University, \\ 1-14 Bunkyo-machi, Nagasaki 852-8521, Japan
}

\begin{abstract}
Asymmetric desymmetrization of meso-vic-diols was performed by tosylation in the presence of copper(II) triflate and $(R, R)-\mathrm{Ph}-\mathrm{BOX}$ as a catalyst. The method was successfully applied to asymmetric desymmetrization of cyclic and acyclic meso-vic-diols in high enantioselectivity with up to $>99 \%$ ee.
\end{abstract}

Nonenzymatic asymmetric desymmetrization of meso-vic-diols is a practically useful methodology for preparation of optically active compounds. ${ }^{1}$ We have exploited an efficient method for kinetic resolution and asymmetric desymmetrization of vic-diols $\mathbf{1}$, which is based on recognition of the vic-diol moiety by a copper(II) ion associated with a chiral ligand $(R, R)-\mathrm{Ph}-\mathrm{BOX}^{2}$ to afford the activated vic-diol intermediates 2 followed by benzoylation under basic conditions 4 (Eq 1). ${ }^{3}$

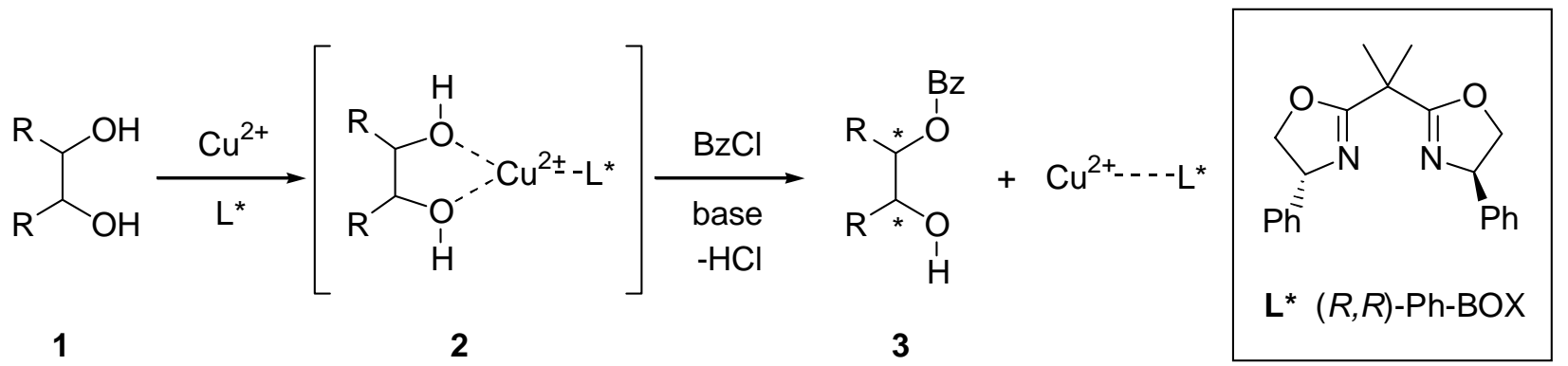

Basic conditions were essential in the benzoylation to remove the generated hydrogen chloride. However, the product sometimes suffered from acyl transfer reaction ${ }^{4}$ under this conditions, decreasing the enantioselectivity of product 3 . To solve this problem, we recently reported an asymmetric desymmetrization of meso-1 by carbamoylation with phenylisocyanate ( $\mathrm{PhNCO}$ ) under non-basic condition to afford optically active vic-diol derivatives (Eq 2). ${ }^{5}$<smiles>[R]C(O)C([R])O</smiles>

meso-1

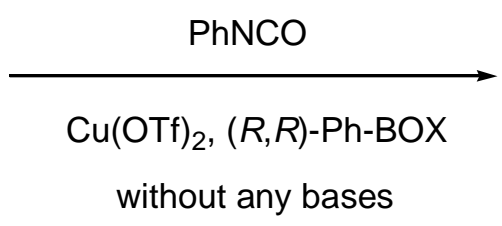

without any bases<smiles>[R]C(O)C([R])OC(=O)Nc1ccccc1</smiles>

4

$64-93 \%$ ee

However, in some cases, the enantioselectivity of monocarbamoylated products did not meet our expectations. $^{5}$ We report herein an asymmetric desymmetrization of meso-vic-diols 1 by monosulfonylation $^{6}$ to afford optically active vic-diol derivatives with high yields and excellent enantioselectivities. 
We began by trying the asymmetric tosylation of meso-1,2-cyclohexanediol $\mathbf{1 a}$ as a model compound in the reaction with $p$-toluenesulfonyl chloride $\mathbf{5 p}$, in the presence of copper (II) triflate and $(R, R)-\mathrm{Ph}$-BOX as a catalyst under different solvents and bases (Eq 3$)^{7}$ The results are summarized in Table 1, which shows a dependence of the yield and \% ee of the product 6ap on the used bases and solvents. The use of $\mathrm{CH}_{2} \mathrm{Cl}_{2}$ in combination with $\mathrm{K}_{2} \mathrm{CO}_{3}$ gave both high yield (94\%) and high enantioselectivity (97\% ee) (entry 1). ${ }^{8}$ Although AcOEt and $i$-PrOH gave high enantioselectivities, their yields were moderate compared to that of $\mathrm{CH}_{2} \mathrm{Cl}_{2}$ (entries 2 and 3) THF and $\mathrm{MeCN}$ gave moderate ees with low yields (entries 4 and 5). On the other hand, screening of bases shows that $\mathrm{NaHCO}_{3}$ is as good a base for this reaction as $\mathrm{K}_{2} \mathrm{CO}_{3}$ (entry 8). Other bases fall short either in terms of yield or enantioselectivity (entries 6, 7, 9-11).<smiles>O[C@H]1CCCC[C@H]1O</smiles>

1a

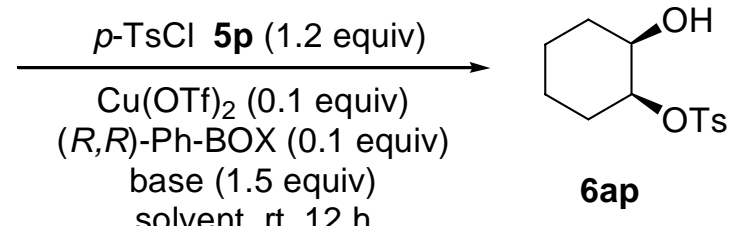

solvent, rt, $12 \mathrm{~h}$
(3)

$6 a p$

Table 1. Asymmetric tosylation of meso-1,2-cyclohexanediol (1a) ${ }^{\mathrm{a}}$

\begin{tabular}{rllll}
\hline Entry & Solvent & Base & \multicolumn{2}{c}{ Product 6ap } \\
\cline { 3 - 5 } & & & Yield (\%) & ee (\%) \\
\hline 1 & $\mathrm{CH}_{2} \mathrm{Cl}_{2}$ & $\mathrm{~K}_{2} \mathrm{CO}_{3}$ & 94 & 97 \\
2 & $\mathrm{AcOEt}$ & $\mathrm{K}_{2} \mathrm{CO}_{3}$ & 58 & 88 \\
3 & $i-\mathrm{PrOH}$ & $\mathrm{K}_{2} \mathrm{CO}_{3}$ & 73 & 92 \\
4 & $\mathrm{THF}$ & $\mathrm{K}_{2} \mathrm{CO}_{3}$ & 25 & 72 \\
5 & $\mathrm{MeCN}_{2}$ & $\mathrm{~K}_{2} \mathrm{CO}_{3}$ & 50 & 80 \\
6 & $\mathrm{CH}_{2} \mathrm{Cl}$ & 18 & 92 \\
7 & $\mathrm{Li}_{2} \mathrm{CO}_{3}$ & 68 & 94 \\
8 & $\mathrm{CH}_{2} \mathrm{Cl}_{2}$ & $\mathrm{Na}_{2} \mathrm{CO}_{3}$ & 91 & 95 \\
9 & $\mathrm{CH}_{2} \mathrm{Cl}_{2}$ & $\mathrm{NaHCO}_{3}$ & 17 & 22 \\
10 & $\mathrm{CH}_{2} \mathrm{Cl}_{2}$ & $\mathrm{Cs}_{2} \mathrm{CO}_{3}$ & 55 & 74 \\
11 & $\mathrm{CH}_{2} \mathrm{Cl}_{2}$ & $\mathrm{DIPEA}_{2}$ & 39 & 63 \\
\hline
\end{tabular}

a $1 \mathrm{a}(0.5 \mathrm{mmol}), \mathrm{Cu}(\mathrm{OTf})_{2}(0.05 \mathrm{mmol}),(R, R)-\mathrm{Ph}-\mathrm{BOX}(0.05 \mathrm{mmol}), p-\mathrm{TsCl} 5 \mathrm{p}$ $(0.6 \mathrm{mmol})$, base $(0.75 \mathrm{mmol})$ in a solvent $(2.0 \mathrm{~mL})$ at $\mathrm{rt}$ for $12 \mathrm{~h}$.

${ }^{\mathrm{b}}$ Determined by HPLC.

In addition to tosyl chloride, a variety of sulfonyl chlorides 5q-t (entries 1-4) except for mesyl chloride 5u (entry 5) were usable for asymmetric sulfonylation of $\mathbf{1 a}$ under the same reaction condition as entry 1 in Table 1 (Eq 4). The results are summarized in Table 2.<smiles>O[C@H]1CCCC[C@H]1O</smiles>

$1 \mathrm{a}$

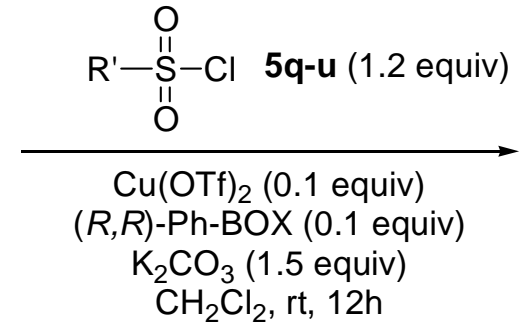


Table 2. Sulfonylation of $1 \mathrm{a}$ with various sulfonyl chlorides $5 \mathrm{q}-\mathbf{u}^{\mathrm{a}}$

\begin{tabular}{|c|c|c|c|c|}
\hline Entry & $\mathrm{R}^{\prime}$ & Product & Yield (\%) & ee $(\%)^{b}$ \\
\hline 1 & $5 q: P h$ & $6 a q$ & 91 & 98 \\
\hline 2 & $5 \mathrm{r}: p-\mathrm{NO}_{2} \mathrm{Ph}$ & $6 a r$ & 59 & 92 \\
\hline 3 & $5 s: p-C I P h$ & 6as & 93 & 93 \\
\hline 4 & $5 t: p-\mathrm{MeOPh}$ & 6at & 61 & 94 \\
\hline 5 & $5 u: M e$ & 6au & 93 & 77 \\
\hline
\end{tabular}

a 1a $(0.5 \mathrm{mmol}), \mathrm{Cu}(\mathrm{OTf})_{2}(0.05 \mathrm{mmol}),(R, R)-\mathrm{Ph}-\mathrm{BOX}(0.05 \mathrm{mmol})$, sulfonyl chloride $5 \mathrm{q}-\mathrm{u}(0.6 \mathrm{mmol}), \mathrm{K}_{2} \mathrm{CO}_{3}(0.75 \mathrm{mmol})$ in $\mathrm{CH}_{2} \mathrm{Cl}_{2}(2.0 \mathrm{~mL})$ at rt for $12 \mathrm{~h}$.

${ }^{\mathrm{b}}$ Determined by HPLC

Then, in order to confirm generality and superiority of tosylation to benzoylation or phenylcarbamoylation, we investigated the asymmetric tosylation, benzoylation, and phenylcarbamoylation of various meso-vic-diols $\mathbf{1 b}-\mathbf{l}$ (Eq 5). ${ }^{9}$ The results are summarized in Table 3. Although meso-1,2-cyclopentanediols (1b) was transformed into the benzoylated product $\mathbf{3 b}$ in racemic form and the phenylcarbamoylated product $\mathbf{4 b}$ in moderate enantiomeric exess ( $72 \%$ ee), we succeeded in obtaining the tosylated product $\mathbf{6 b p}$ in $91 \%$ yield and $95 \%$ ee (entry 1). Various meso-cycloalkaneand meso-cycloalkene-diols $\mathbf{1 c - g}$ other than $\mathbf{1 b}$ were asymmetrically tosylated to afford monotosylated products 6cp-6gp in better yield and higher enantioselectivity than that of monobenzoylated products 3c-g and monocarbamoylated products $\mathbf{4 c - g}$ (entries 2-6). Important to note is the asymmetric tosylation of nitrogen, oxygen, and sulfur atom-containing five membered diols $\mathbf{1 h}$-j to obtain $\mathbf{6 b p}$,hp-jp were much more effective than that of benzoylation and carbamoylation, respectively (entries 7-9). In the case of acyclic 1,2-diols $\mathbf{1 k}$ and $\mathbf{1 1}$, asymmetric tosylation afforded excellent results similar to those of benzoylation but which were better than carbamoylation results (entries 10 and 11).
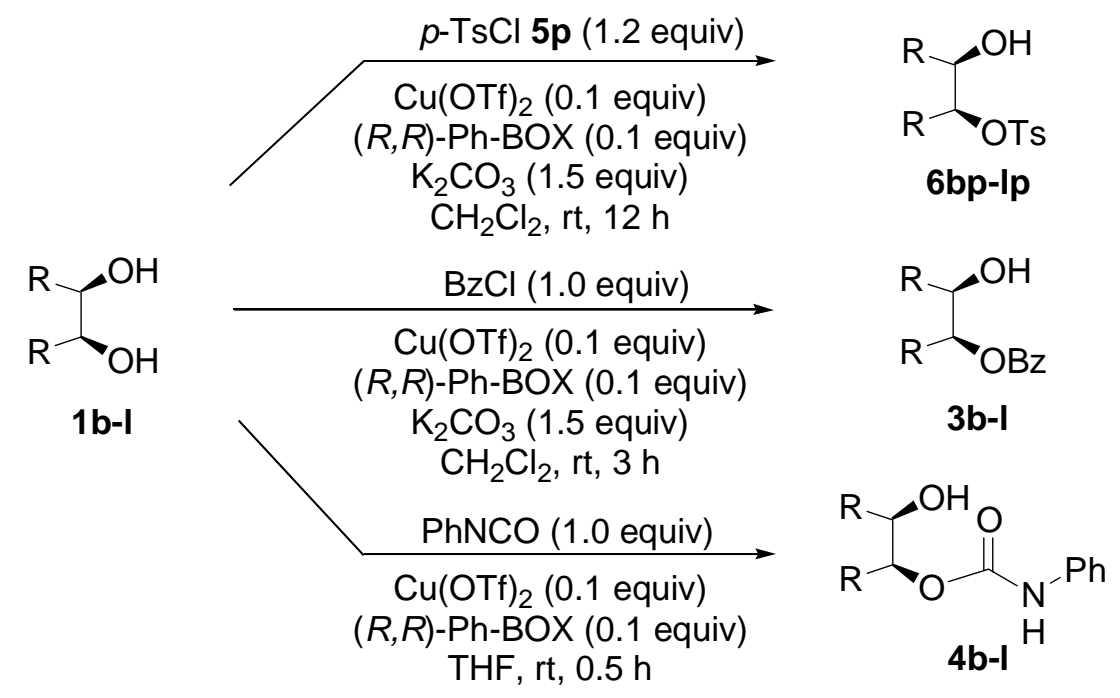


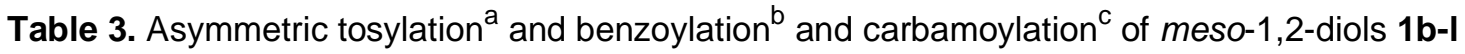

\begin{tabular}{|c|c|c|c|c|c|c|c|c|c|c|c|}
\hline \multirow[t]{2}{*}{ Entry } & \multirow{2}{*}{\multicolumn{2}{|c|}{ Substrate }} & \multicolumn{3}{|c|}{ Tosylated product } & \multicolumn{3}{|c|}{ Benzoylated product } & \multicolumn{3}{|c|}{ Carbamoylated product } \\
\hline & & & & $d(\%)$ & $\overline{e e}(\%)^{d}$ & Yie & $d(\%)$ & $\overline{e e}(\%)^{d}$ & Yielo & (\%) & ee $(\%)^{d}$ \\
\hline 1 & $1 b$ & & $6 \mathrm{bp}$ & 91 & 95 & $3 b$ & 47 & 3 & $4 b$ & 91 & 72 \\
\hline 2 & $1 c$ & & $6 \mathrm{cp}$ & 81 & 99 & $3 c$ & 88 & 58 & 4c & 83 & 83 \\
\hline 3 & 1d & & $6 \mathrm{dp}$ & 96 & 98 & 3d & 85 & 65 & $4 d$ & 96 & 86 \\
\hline 4 & $1 e$ & & 6ep & $>99$ & 97 & $3 e$ & 68 & 93 & $4 e$ & 96 & 59 \\
\hline 5 & $1 f$ & & $6 f p$ & $>99$ & 99 & $3 f$ & 89 & 96 & $4 f$ & 88 & 67 \\
\hline 6 & $1 \mathrm{~g}$ & & $6 \mathrm{gp}$ & 86 & 98 & $3 g$ & 92 & 80 & $4 g$ & 86 & 50 \\
\hline 7 & $1 \mathrm{~h}$ & $\mathrm{Bz}$ & $6 h p$ & 99 & 94 & $3 h$ & 82 & racemic & $4 h$ & 91 & 72 \\
\hline 8 & $1 \mathrm{i}$ & & $6 i p$ & 80 & 95 & $3 \mathbf{i}$ & 81 & racemic & $4 i$ & 99 & 64 \\
\hline 9 & $1 \mathrm{j}$ & & $6 \mathrm{jp}$ & 93 & 94 & $3 \mathbf{j}$ & 63 & 8 & $4 j$ & 90 & 52 \\
\hline 10 & $1 \mathrm{k}$ & & $6 \mathrm{kp}$ & 88 & $>99$ & $3 k$ & 78 & 97 & $4 k$ & 94 & 70 \\
\hline 11 & 11 & & $61 p$ & 71 & 93 & 31 & 36 & 96 & $4 !$ & 91 & 82 \\
\hline
\end{tabular}

a 1 b-I $(0.5 \mathrm{mmol}), \mathrm{Cu}(\mathrm{OTf})_{2}(0.05 \mathrm{mmol}),(R, R)$ - $\mathrm{Ph}-\mathrm{BOX}(0.05 \mathrm{mmol}), p-\mathrm{TsCl} 5 \mathrm{p}(0.6 \mathrm{mmol}), \mathrm{K}_{2} \mathrm{CO}_{3}(0.75$ $\mathrm{mmol})$ in $\mathrm{CH}_{2} \mathrm{Cl}_{2}(2.0 \mathrm{~mL})$ at rt for $12 \mathrm{~h}$.

${ }^{\mathrm{b}}$ 1b-I $(0.5 \mathrm{mmol}), \mathrm{Cu}(\mathrm{OTf})_{2}(0.05 \mathrm{mmol}),(R, R)-\mathrm{Ph}-\mathrm{BOX}(0.05 \mathrm{mmol}), \mathrm{BzCl}(0.5 \mathrm{mmol}), \mathrm{K}_{2} \mathrm{CO}_{3}(0.75$ $\mathrm{mmol})$ in $\mathrm{CH}_{2} \mathrm{Cl}_{2}(2.0 \mathrm{~mL})$ at rt for $3 \mathrm{~h}$.

${ }^{\mathrm{C}}$ 1b-I (0.5 mmol), $\mathrm{Cu}(\mathrm{OTf})_{2}(0.05 \mathrm{mmol}),(R, R)-\mathrm{Ph}-\mathrm{BOX}(0.05 \mathrm{mmol}), \mathrm{PhNCO}(0.5 \mathrm{mmol})$, in THF (2.0 $\mathrm{mL})$ at $\mathrm{rt}$ for $0.5 \mathrm{~h}$.

${ }^{d}$ Determined by HPLC. 
In some cases, the reason why the tosylated products were obtained with higher enantioselectivity than the benzoylated products may be explained as follows. In the case of benzoylation, intramolecular acyl transfer of optically active 3a occurred for it to lose some extent of its optical activity when 3a was subjected to the basic conditions for a long time (Eq 6). ${ }^{4}$ On the other hand, acyl transfer of the monotosylated product 6ap did not occur under the basic conditions, so 6ap was obtained with high optical purity (Eq 7).<smiles>CC(C)(C)OC1CCCCC1O</smiles>

$3 a$ $95 \%$ ee<smiles>[O+]C1CCCCC1O</smiles>
6ap $97 \%$ ee
$\mathrm{CH}_{2} \mathrm{Cl}_{2}, \mathrm{rt}, 12 \mathrm{~h}$

in the presence of

$\mathrm{K}_{2} \mathrm{CO}_{3}$ (1.5 equiv)

$\mathrm{Cu}(\mathrm{OTf})_{2}$ (0.1 equiv), $(R, R)$ - $\mathrm{Ph}-\mathrm{BOX}$ ( 0.1 equiv)

$\mathrm{Cu}(\mathrm{OTf})_{2}$ (0.1 equiv), $(R, R)$-Ph-BOX (0.1 equiv), $\mathrm{K}_{2} \mathrm{CO}_{3}$ (1.5 equiv) 3a

quant. yield, $82 \%$ ee quant. yield, $95 \%$ ee quant. yield, $32 \%$ ee

\section{6ap}

quant. yield, $97 \%$ ee quant. yield, $97 \%$ ee quant. yield, $97 \%$ ee

The absolute stereoconfiguration of 6ap was determined to be $(1 S, 2 R)$ by transformation of 6ap to $(1 S, 2 R)-(-)-7^{10}(\mathrm{Eq} 8)$ which was the same stereoconfiguration of $(1 S, 2 R)-(-)-7$ derived from reported 8 (Eq 9). ${ }^{11}$

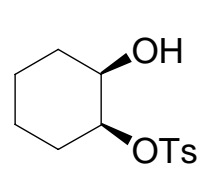

$6 a p$

$97 \%$ ee<smiles>O=C(O)OC1CCCCC1O</smiles>

8

$93 \%$ ee

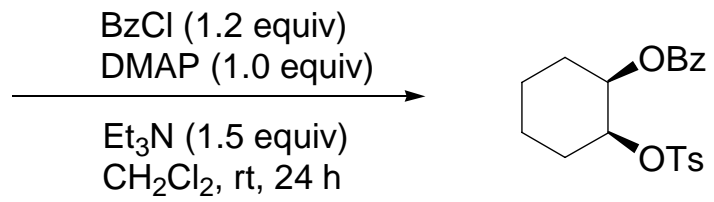

7

$84 \%$ yield, $97 \%$ ee

$$
[\alpha]^{27}-12.2\left(c 1.0, \mathrm{CHCl}_{3}\right)
$$
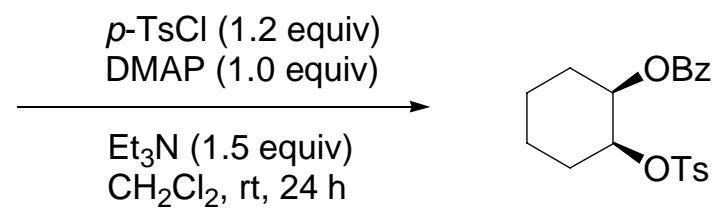

7

$84 \%$ yield, $93 \%$ ee

$[\alpha]^{27}-11.6\left(c 1.0, \mathrm{CHCl}_{3}\right)$

It is convenient for chemical transformations of compound $\mathbf{7}$ into optically active compounds 9-11 that tosyloxy substituent of compound 7 is a good leaving group for $\mathrm{S}_{\mathrm{N}} 2$ reaction and $\mathrm{E} 2$ reaction. At first, 7 was treated with $\mathrm{NaN}_{3}$ to obtain the azide compound 9 with complete stereoinversion, followed by reduction and benzoylation to afford the optically active vic-amino alcohol $\mathbf{1 0}$ (Eq 10). ${ }^{12,14}$ Also 7 was treated with DBU to obtain the optically active $\alpha, \beta$-unsaturated alcohol derivative $\mathbf{1 1}$ in good yield without any loss of the optical purity of 7 (Eq 11). ${ }^{15}$ 
<smiles>O=C(O)OC1CCCCC1[O-]</smiles>

7

$97 \%$ ee

7

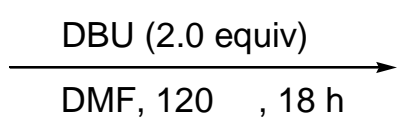

$97 \%$ ee

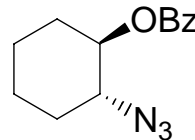

9

97\% yield
1) $\mathrm{H}_{2}, \mathrm{Pd}-\mathrm{C}, \mathrm{MeOH}$

2) $\mathrm{BzCl}$ (1.2 equiv) $\mathrm{Et}_{3} \mathrm{~N}$ (2.0 equiv) DMAP ( 0.2 equiv) $\mathrm{CH}_{2} \mathrm{Cl}_{2}$, rt, $12 \mathrm{~h}$

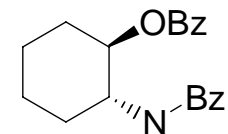

$\mathrm{H}$

10
$85 \%$ yield, $97 \%$ ee

11

$80 \%$ yield, $97 \%$ ee

The results shown in this communication are practical method for a preparation of optically active monotosylated derivatives from meso-vic-diols. Asymmetric monotosylation method has generality for various meso-vic-diols and is superior to monobenzoylation or monocarbamoylation method. The mechanistic study of this monotosylation and its application to a kinetic resolution of $d l$-vic-diols are now under investigation.

\section{Acknowledgements}

This study was supported by a Grant-in-Aid for Scientific Research (B) (No. 17350051) from Japan Society for the Promotion of Science.

This paper is dedicated to the heartfelt memory of the late Professor Yoshihiro Matsumura of Nagasaki University.

\section{References and notes}

1. Representative literatures for nonenzymatically asymmetric monobenzoylation of meso-vic-diols: (a) Oriyama, T.; Imai, K.; Hosoya, T.; Sano, T. Tetrahedron Lett. 1998, 39, 3529-3532. (b) Mizuta, S.; Sadamori, M.; Fujimoto, T.; Yamamoto, I. Angew. Chem., Int. Ed. 2003, 42, 3383-3385. (c) Vedejs, E.; Daugulis, O.; Tuttle, N. J. Org. Chem. 2004, 69, 1389-1392. (d) Mazet, C.; Köhler, V.; Pfaltz, A. Angew. Chem., Int. Ed. 2005, 44, 4888-4891. (e) Yamada, S.; Misono, T.; Iwai, Y.; Masumizu, A.; Akiyama, Y. J. Org. Chem. 2006, 71, 6872 - 6880. (f) Nakamura, D.; Kakiuchi, K.; Koga, K.; Shirai, R. Org. Lett. 2006, 8, 6139-6142. (g) Arai, T.; Mizukami, T.; Yanagisawa, A. Org. Lett. 2007, 9, 1145-1147.

2. For $(S, S)-P h-B O X$ : (a) Corey, E. J.; Imai, N.; Zhang, H.-Y. J. Am. Chem. Soc. 1991, 113, 728-729; A recent review of chiral bis(oxazoline) ligands: (b) Desimoni, G..; Faita, G.; Jørgensen, K. A. Chem. Rev. 2006, 106, 3561-3651.

3. (a) Matsumura, Y.; Maki, T.; Murakami, S.; Onomura. O. J. Am. Chem. Soc. 2003, 125, 2052-2053;

(b) Matsumura, Y.; Maki, T.; Tsurumaki, K.; Onomura, O. Tetrahedron Lett. 2004, 45, 9131-9134.

(c) Matsumura, Y.; Onomura, O.; Demizu, Y. Yuki Gosei Kagaku Kyokaishi 2007, 65, 216-225.

4. Edin, M.; Martín-Matute, B.; Bäckvall J.-E. Tetrahedron: Asymmetry 2006, 17, 708-715.

5. Matsumoto, K.; Mitsuda, M.; Ushijima, N.; Demizu, Y.; Onomura, O.; Matsumura, Y. Tetrahedron Lett. 2006, 47, 8453-8456.

6. Regioselective sulfonylation of vic-diols catalyzed by tin compounds (a) Bucher, B.; Curran, D. P. Tetrahedron Lett. 2000, 41, 9617-9621. (b) Martinelli, M. J.; Vaidyanathan, R.; Pawlak, J. M.; Nayyar, N. K.; Dhokte, U. P.; Doecke, C. W.; Zollars, L. M. H.; Moher. E. D.; Khau, V. V.; Kosmrlj, 
B. J. Am. Chem. Soc. 2002, 124, 3578-3585.

7. A typical procedure for asymmetric monotosylation: Under an aerobic atmosphere, a solution of $\mathrm{Cu}(\mathrm{OTf})_{2}(18.1 \mathrm{mg}, 0.05 \mathrm{mmol})$ and $(R, R)-\mathrm{Ph}-\mathrm{BOX}(16.7 \mathrm{mg}, 0.05 \mathrm{mmol})$ in $\mathrm{CH}_{2} \mathrm{Cl}_{2}(2 \mathrm{~mL})$ was stirred for $10 \mathrm{~min}$. Into the solution were added meso-1a $(0.5 \mathrm{mmol}), \mathrm{K}_{2} \mathrm{CO}_{3}(103.7 \mathrm{mg}, 0.75 \mathrm{mmol})$ and $p$-TsCl $5 p$ (114.4 mg, $0.6 \mathrm{mmol})$. After being stirred for $12 \mathrm{~h}$ at $\mathrm{rt}$, the solution was poured in water and extracted with AcOEt $\left(20 \mathrm{~mL}\right.$ x 3). The combined organic layer was dried over $\mathrm{MgSO}_{4}$ and the solvent removed under reduced pressure. The residue was purified by silica gel column chromatography ( $n$-hexane : AcOEt $=3: 1)$ to afford $(1 S, 2 R)$-6ap (94\% yield, $97 \%$ ee) as a colorless oil. $[\alpha]^{19}{ }_{\mathrm{D}}-8.1$ (c 1.0, $\left.\mathrm{CHCl}_{3}\right)$. IR (neat) $3530,2942,1599,1356,1175 \mathrm{~cm}^{-1}$. ${ }^{1} \mathrm{H}$ NMR $(300 \mathrm{MHz}$, $\left.\mathrm{CDCl}_{3}\right) \delta 7.82(\mathrm{~d}, J=8.7 \mathrm{~Hz}, 2 \mathrm{H}), 7.35(\mathrm{~d}, J=7.8 \mathrm{~Hz}, 2 \mathrm{H}), 4.68-4.58(\mathrm{~m}, 1 \mathrm{H}), 3.88-3.78(\mathrm{~m}, 1 \mathrm{H})$, $2.45(\mathrm{~s}, 3 \mathrm{H}), 2.10-1.20(\mathrm{~m}, 9 \mathrm{H}) .{ }^{13} \mathrm{C} \mathrm{NMR}\left(75 \mathrm{MHz}, \mathrm{CDCl}_{3}\right) \delta 144.6,134.0,129.7,127.5,83.0,68.8$, 30.1, 27.5, 21.5(2C), 20.6. MS [LR-FAB $(+)]: m / z 271[\mathrm{M}+\mathrm{H}]^{+}$. The optically purity of 6 ap was determined by chiral HPLC: Daicel Chiralcel OJ-H column (4.6 mm $\phi, 250 \mathrm{~mm}), n$-hexane : $i$-PrOH $=10: 1$, wavelength: $220 \mathrm{~nm}$, flow rate: $1.0 \mathrm{ml} / \mathrm{min}$, retention time: $15.2 \mathrm{~min}((1 R, 2 S)-(+)-6 \mathbf{a p})$, $16.9 \min ((1 S, 2 R)-(-)$-6ap).

8. The use of $\mathrm{CuCl}_{2}$ instead of $\mathrm{Cu}(\mathrm{OTf})_{2}$ reduced the yield and $\%$ ee of the product $6 \mathbf{a p}(69 \%$ yield, $88 \%$ ee, respectively).

9. Monotosylation, monobenzoylation, and monophenylcarbamoylation of meso-vic-diols in the presence of $(R, R)-\mathrm{Ph}-\mathrm{BOX}$ occurred at the same position. The absolute stereoconfiguration of 6bp-6lp shown in Eq 5 and Table 3 was deduced on the basis of that of 6ap.

10. Chiral HPLC condition: Daicel Chiralcel OJ-H column $(4.6 \mathrm{~mm} \phi, 250 \mathrm{~mm}), n$-hexane : isopropanol $=5: 1$, wavelength: $220 \mathrm{~nm}$, flow rate: $1.0 \mathrm{ml} / \mathrm{min}$, retention time: $12.3 \mathrm{~min}((1 S, 2 R)-(-)-7), 19.5$ $\min ((1 R, 2 S)-(+)-7)$.

11. Kawabata, T.; Nagato, M.; Takasu, K.; Fuji, K. J. Am. Chem. Soc. 1997, 119, 3169-3170.

12. Compound $(1 R, 2 R)-(-)-\mathbf{1 0}: \mathrm{mp} 149-151{ }^{\circ} \mathrm{C}$. $[\alpha]^{21} \mathrm{D}-89.2\left(c 1.0, \mathrm{CHCl}_{3}\right)\left[\operatorname{lit}^{13}(1 S, 2 S)-(+)-10 ;[\alpha]^{12}{ }_{\mathrm{D}}\right.$ $\left.+60.5\left(c 1.0, \mathrm{CHCl}_{3}\right)\right]$. HPLC chiralcel OD column $(4.6 \mathrm{~mm} \phi, 250 \mathrm{~mm}), n$-hexane $: i$-PrOH $=20: 1$, wavelength: $220 \mathrm{~nm}$, flow rate: $1.0 \mathrm{ml} / \mathrm{min}$, retention time: $11.1 \mathrm{~min}((1 S, 2 S)-(+)-10), 14.8 \mathrm{~min}$ $((1 R, 2 R)-(-)-10)$.

13. Nishida, A.; Shirato, F.; Nakagawa, M. Tetrahedron: Asymmetry 2000, 11, 3789 - 3806.

14. Compounds 9, 10 and/or their enantiomers might be good precursors for antiarrhythmic agents: Plouvier, B.; Beatch, G. N.; Jung, G. L.; Zolotoy, A.; Sheng, T.; Clohs, L.; Barret, T. D.; Fedida, D.; Wang, W. Q.; Zhu, J. J.; Liu, Y.; Abraham, S.; Lynn, L.; Dong, Y.; Wall, R. A.; Walker, M. J. A. J. Med. Chem. 2007, 50, 2818-2841.

15. The absolute stereoconfiguration was determined by comparing with specific rotation of authentic sample. See, ref. 16. Compound $(R)-11:[\alpha]^{21}{ }_{\mathrm{D}}+224.9\left(c\right.$ 1.0, $\left.\mathrm{CHCl}_{3}\right)$. [lit. ${ }^{16}(S)-11(86 \%$ ee $) ;[\alpha]^{25}{ }_{\mathrm{D}}$ $-157.0\left(\right.$ ( $\left.\left.0.45, \mathrm{CHCl}_{3}\right)\right]$

16. Sekar, G.; DattaGupta, A.; Singh, V. K. J. Org. Chem. 1998, 63, 2961-2967. 
Graphical Abstract

To create your abstract, type over the instructions in the template box below.

Fonts or abstract dimensions should not be changed or alte

Copper complex catalyzed asymmetric mono-

Leave this area blank for abstract info. sulfonylation of meso vic-diols

Yosuke Demizu, Kazuya Matsumoto, Osamu Onomura, ${ }^{*}$ and Yoshihiro Matsumura

Graduate School of Biomedical Sciences, Nagasaki University, 1-14 Bunkyo-machi, Nagasaki 852-8521, Japan<smiles>[R]C(O)C([R])O</smiles><smiles>C1CC2CC1C2</smiles>

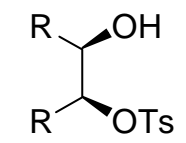

up to $>99 \%$ ee

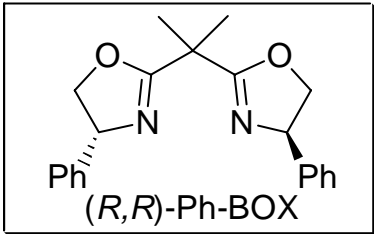


